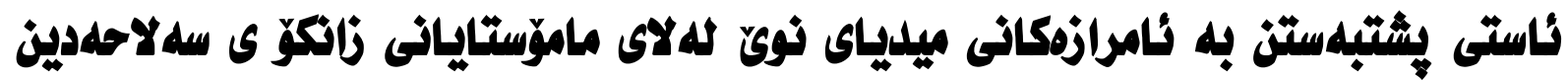

جوان بهاءالدين على

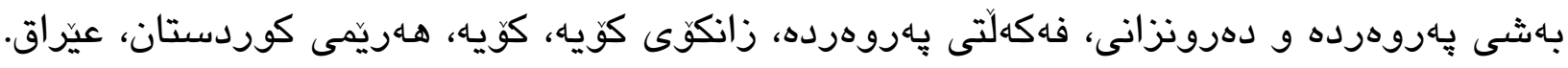

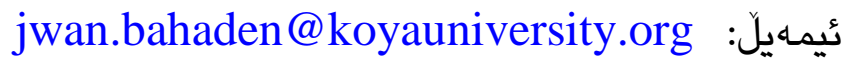

\section{عبدالخالق ابراهيي مصطفى}

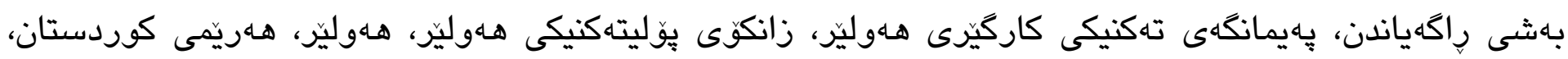
عيّراق. abdulkhaliq.mstaffa@epu.edu.iq :يمهيلّ

\section{يوخته:}

ئامانجى ئهم تويزّزينهوهيه بريتيه له ئاشكراكردنى ئاستى بشتبهستنى ماموستايانى زانكوى سهلاحهدين به ئامِ

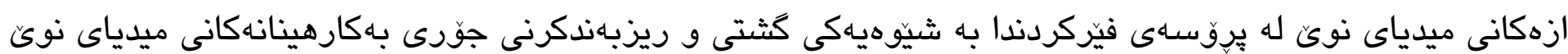

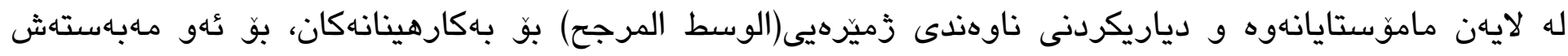

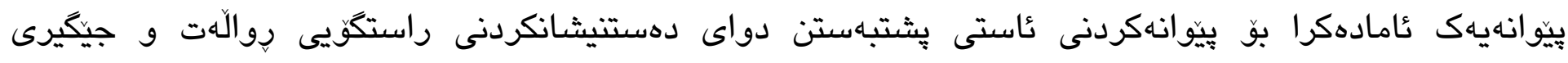

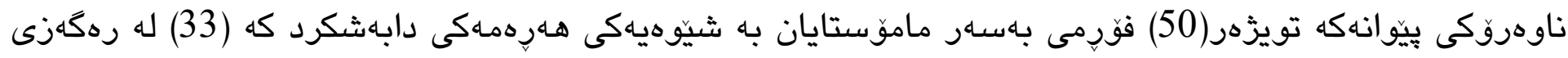
نيّر و (17)ماموّستاش له رهكَز مئ بورون.

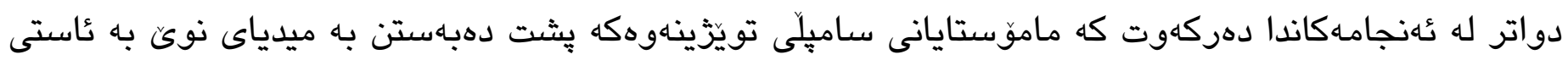

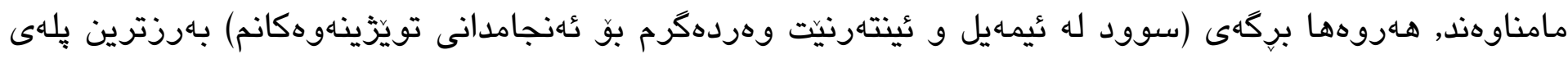

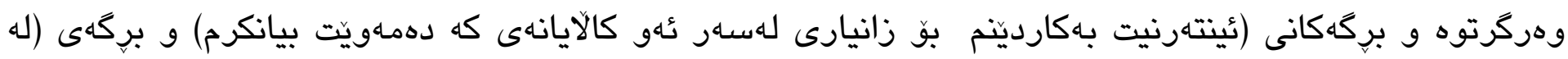

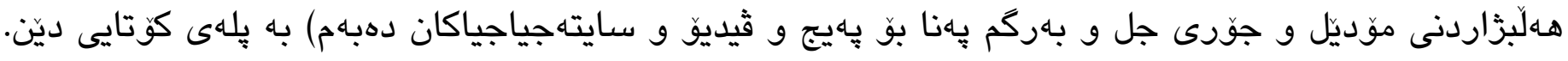
كاليله وشُه: ئاست , بشتباهتن , ميدياى نوىن. 


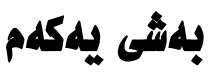

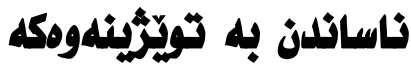

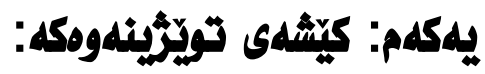

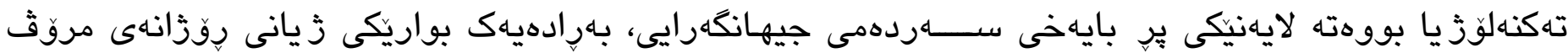

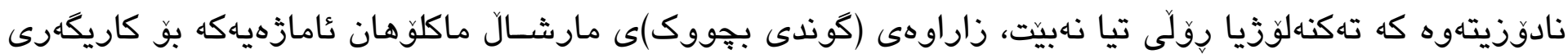
ميديا له سهدهى بيستدا و ئيستا زياتر دهكونجيت لهكهل سهردهمى داهينانه تهكنهلوزَيهكان.

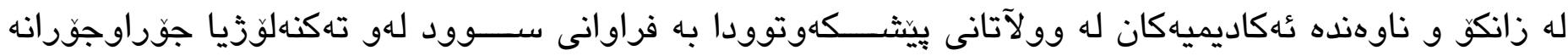

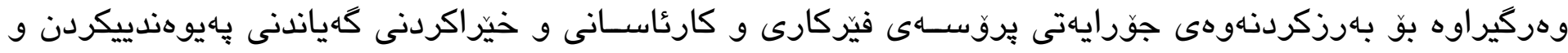

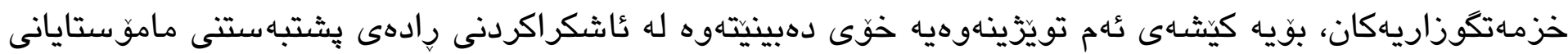

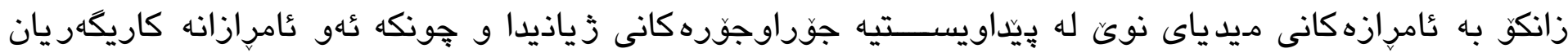

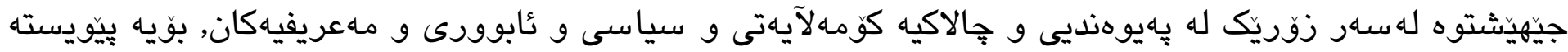

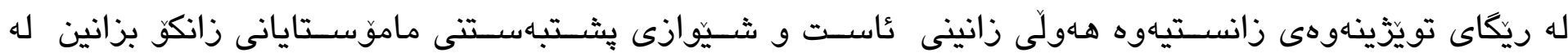
بهارهينانى ميدياى نوكن.

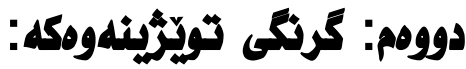

دهكريّت كر نكى ئهم تويَزينهوه لهم خالانهى لاعى خوارهوه بخهينهروو:

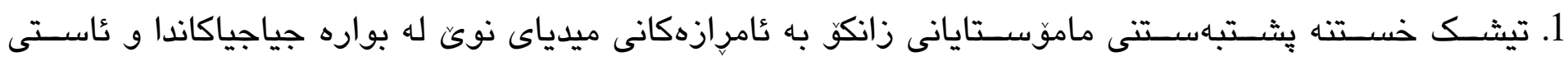

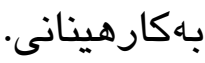

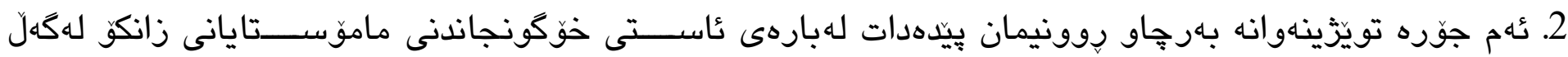

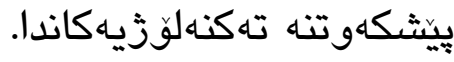

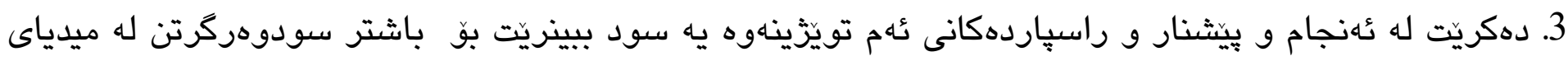
نوني

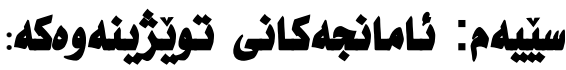

ئامانجى ئهم تويَّزينهوهيه لهم خالآنه خوّى دهبينيتهاوه:-

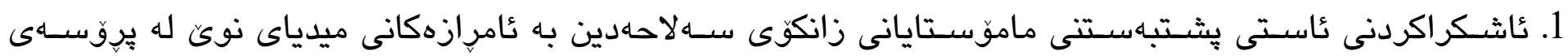

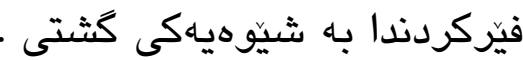




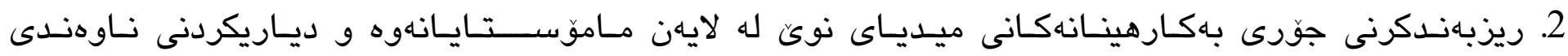

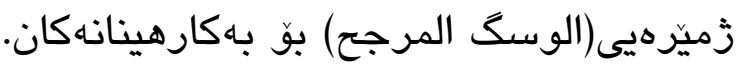

\section{جوارهم: سنورى تويَّرينهومكه:}

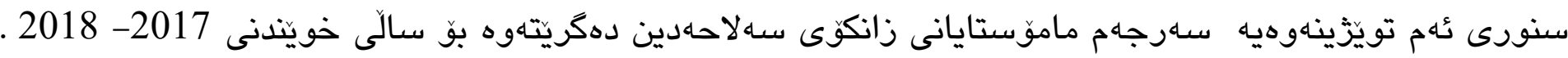

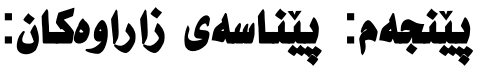

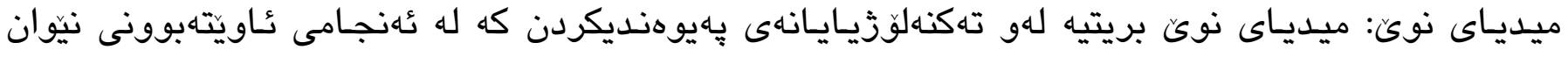

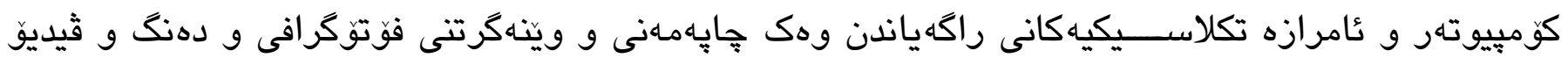

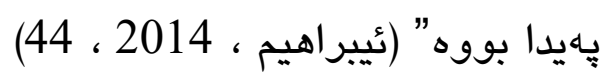

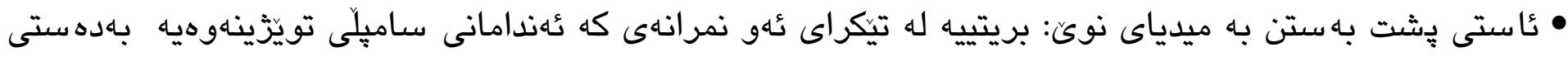

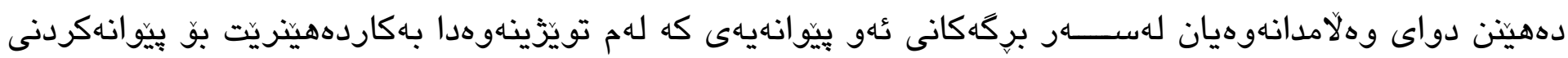

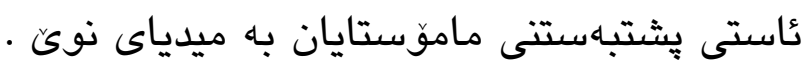

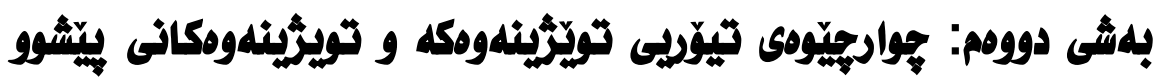

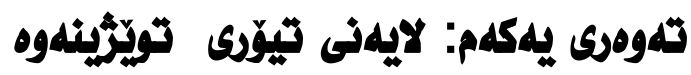

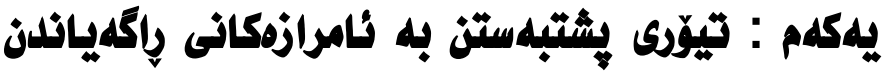

ئهم تيوّره له حهفتاكانى سهادهى بيستهم لهسهر بنهمایى بوونى بهاهيوهندييهكى بهاهيزى نيوان جهاماوهر و ئامرازهكانى

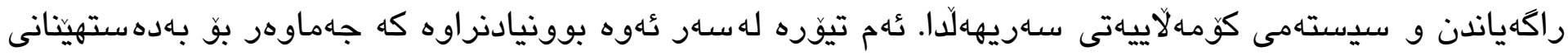

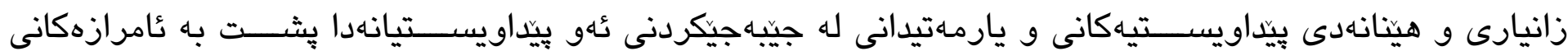

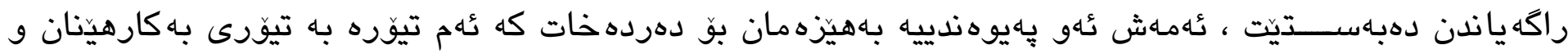

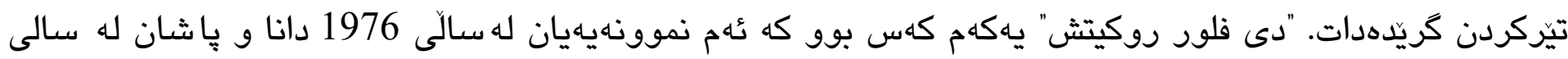

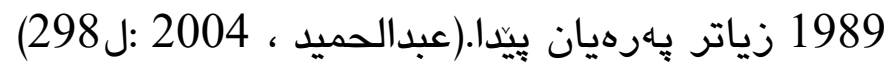

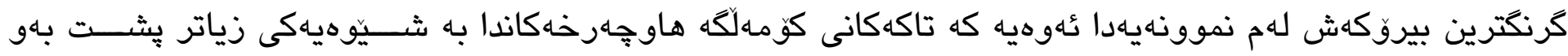

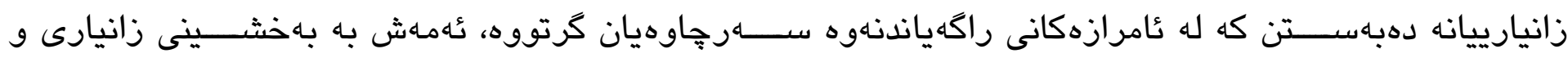

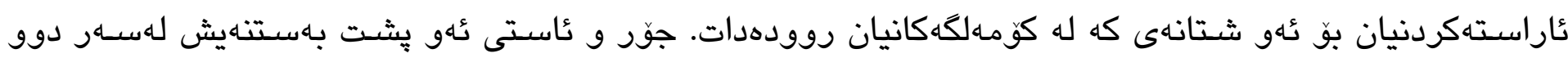

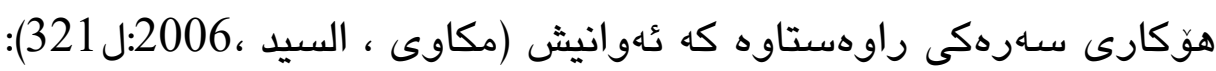
1. يلهى كَورانكارى يان ململاني، ياخود نائارامى كه كومهلكه بهدهستيهوه دهناليتى. 
2. يُلهى بايهخى عامرازهكانى راكهياندن وهكو سهرجاوهيهكى زانيارى كومهلكه. كريمانهكانى نموونهى بشتبهستن يش بريتيه له (حجاب ، 2010 :ل302-303):

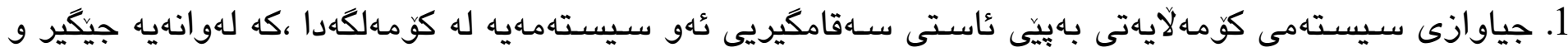

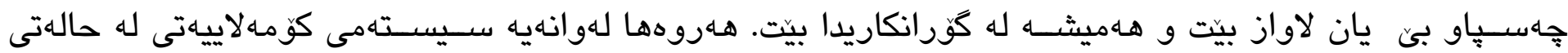

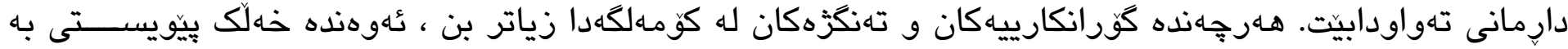

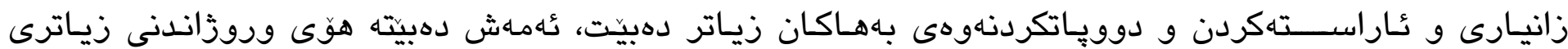

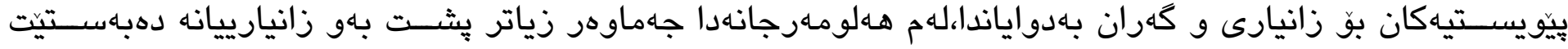

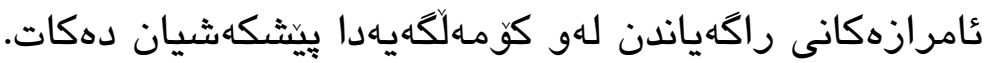

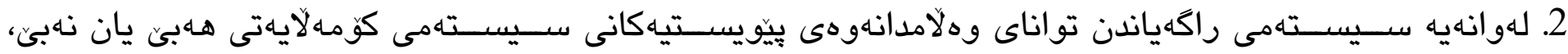

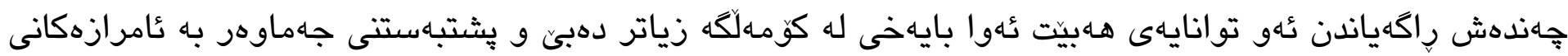
راكهياندن زياتر دهكات.

3. جهماوهر له رووى يُشـتبهسـتنى به ئامرازهانى راكَهياندن له يهكتر جياوازن ، جهماوهرى ســــركردكانى را

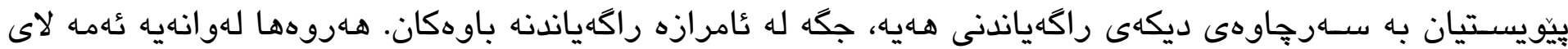
تويّزى ديكهش له جهماوهر بهييّى هـلوماهرج و تايبهتمهندييه كومالآيهتييهكانيان روويدات.

\section{دووم : ناساتلان بله ميلياى نوىن}

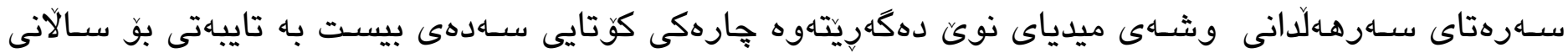

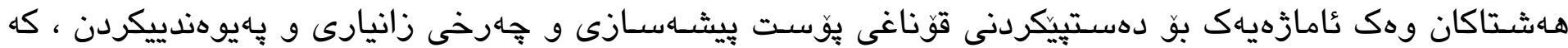

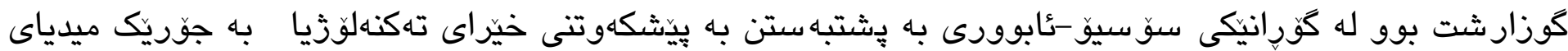

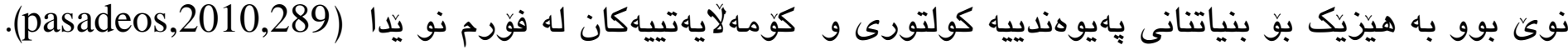

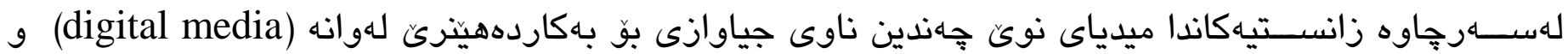
) و و و و جهندين ناوى ديكه كه زياتر رههانده تهكنهلوذى و (interactive media (online media

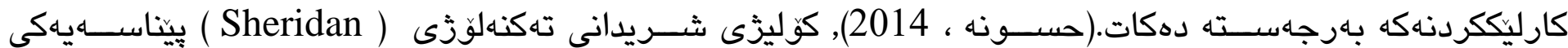

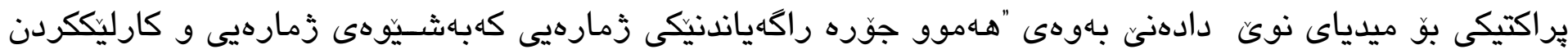

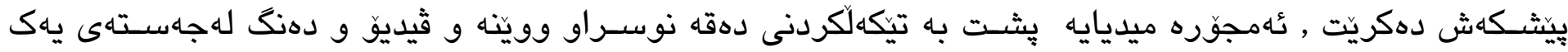

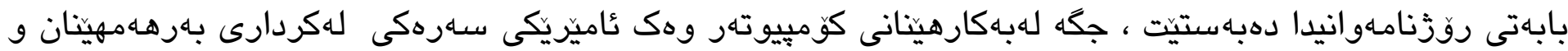

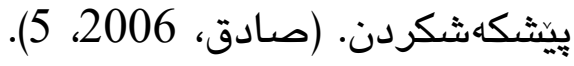




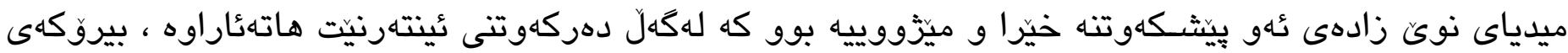

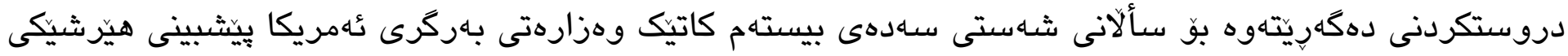

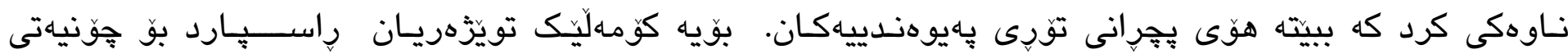

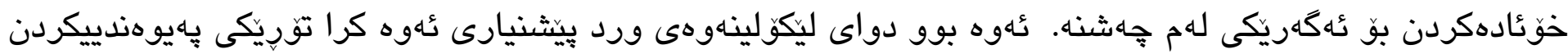
(Network)

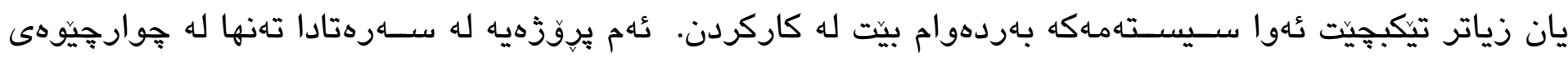

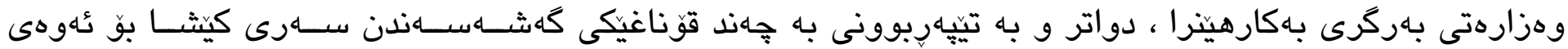
ئيستا به ئينتهنيت (Internet) دهناسريَت كه كورتكراوهى (International Network) (شقره، (2014).

\section{سيّيليdم:تُامرازكانى ميلياى نوىن}

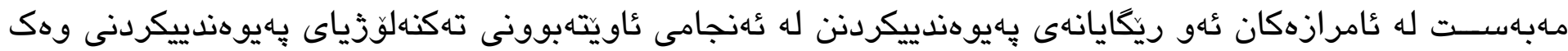

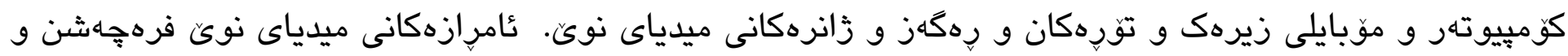

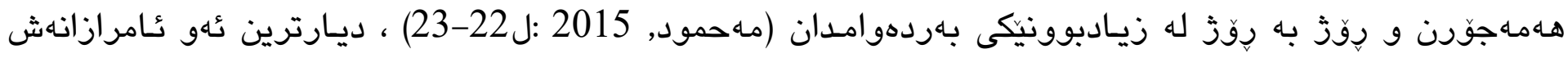
: كُهانه

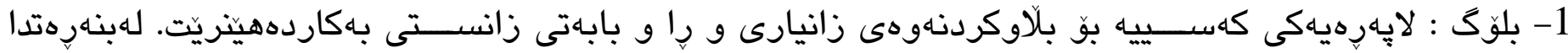

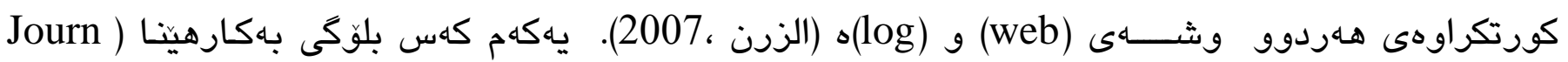
(Barger

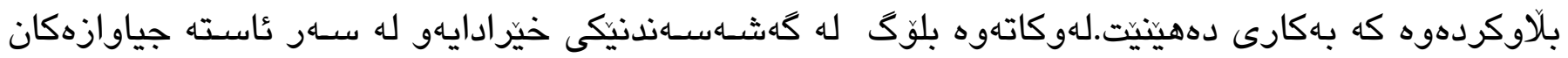
له هـهوو بواره جياجياكاندا بهكاردهينينريّ( Watt , Allan,2013,p124

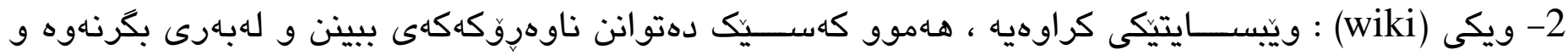

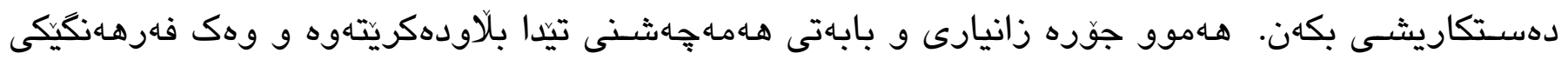
كراوه سـيردهكريخ (Jiravindra,2014,p4).

3- يوّدكاست (podcast) : له هـردوو وشنهى (broadcast) و (ipod)هوه هاتووه كه بريتييه له خزمهتكوزاريهك

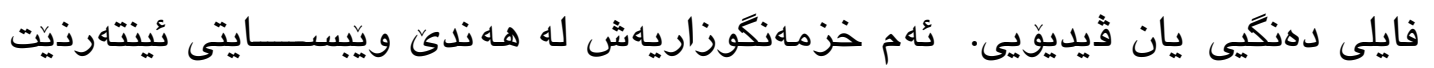

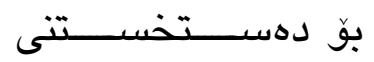
دهستهبهركراوه.

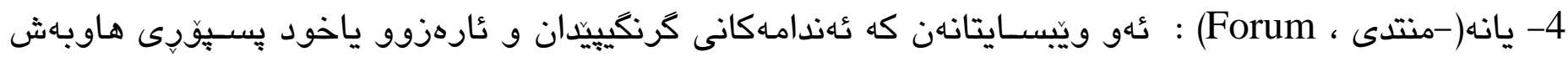

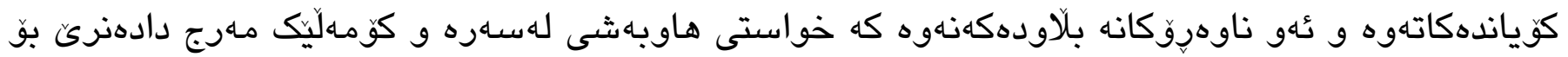

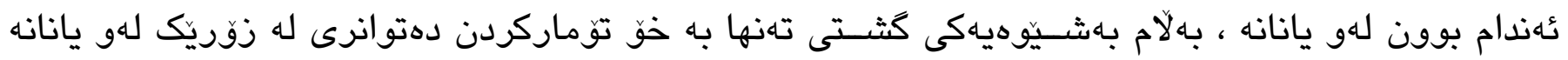
بيته تُهندام(مهاهمود ، 2014 :ل 25). 


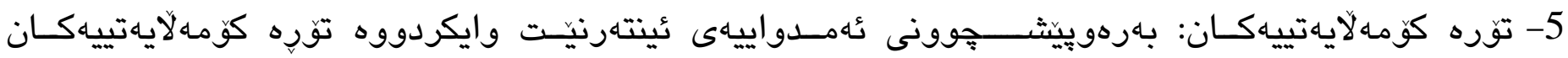

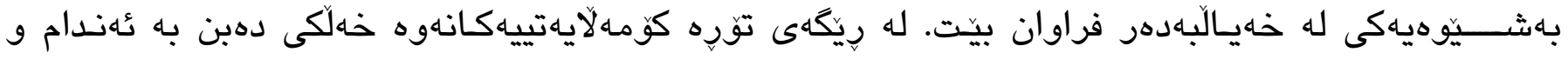

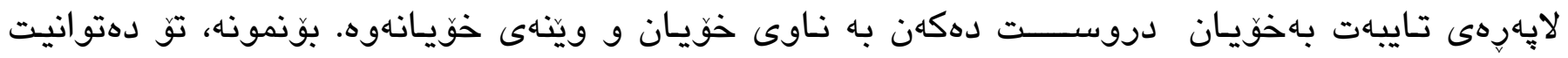
لإِهرهى تايبهتى كهـــــانى ديكه بيينيت كه دهيانتاســـيت و بيانكهيت بـه هاوريّى خوّت. يادهتوانيت هـر له

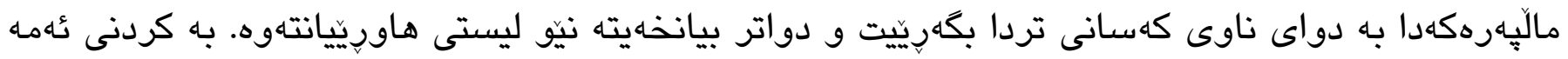

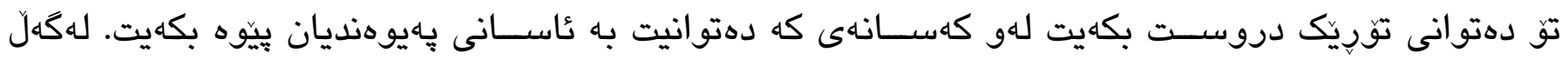

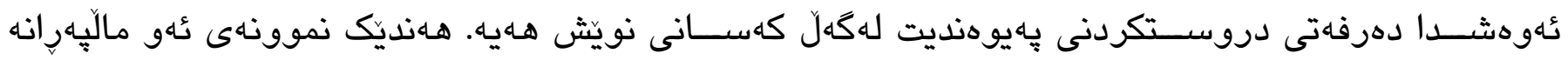
بريتين له فهيسبووك ، ماى سيهيس، تويتهر و يوتيوب (سليم ، 2016 :ل 32) كه ليَرهدا به كورتى بيناسهى هـريـكهيان دهكهين.

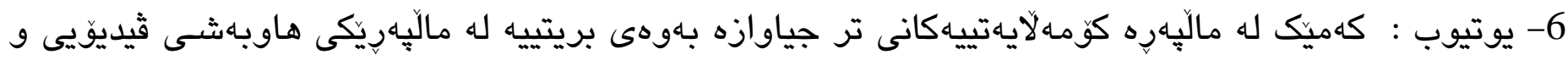

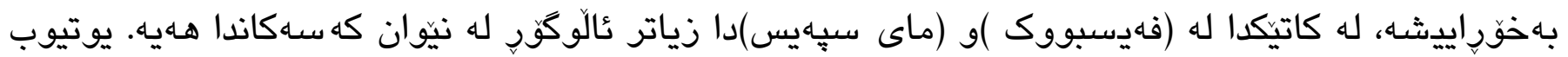
له سالّى (2005 ) لهلايهن (جاد هيّرلى) و (ستيق جِيّن) و (جاويد كهريم)هوه دانراوه. يوتيوب لهوهدا له (مایى

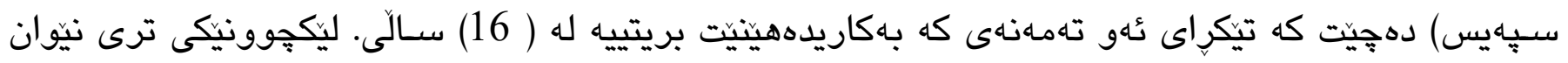
(يوتيوب) و (ماى سيهيس) بريتييه له قازانجهكهى. له سالّى (2006)دا يوتيوب لهلايهن كوميانياى كُكلّوه بـ برِى (65، 1، 1، مليار دولار كردرا. 7- فهيسـبووك: فهيسـبووك كهميكَ جياوازتره له ماى سـيهيس و يوتيوب، بهوهى فهيسـبووك له بنهرهتهوه بو

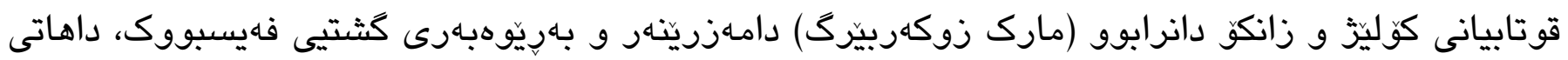
سالآنهى به ( 50) مليَّن دوّلار دهخهملِينريّت. (الفيصل ، 2014 ، 2019

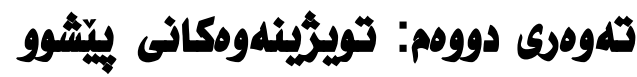

$$
\text { 1 - تويزيناهوهى (شقير , 2009 ) }
$$

ناونيثانى تويّزينهوهكه بريتى بوو له (استخدام اساتذه الجامعه دمشق لانترنت و الاشباعات المحققه منها),

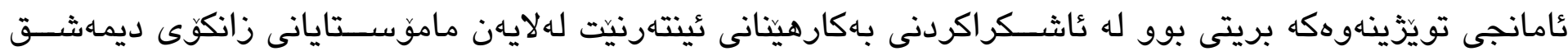

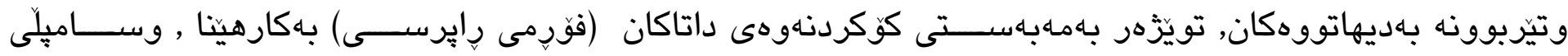
تويَّينهوهكه بريتى بوو له ( 79) ماموّستاى زانكو.

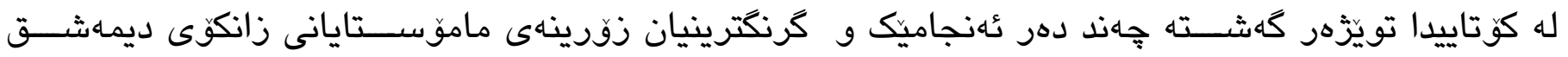

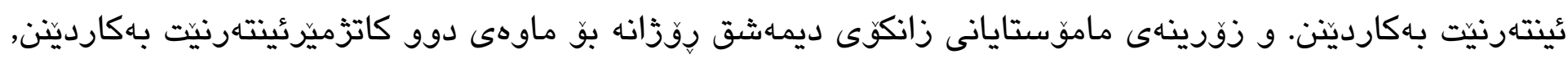

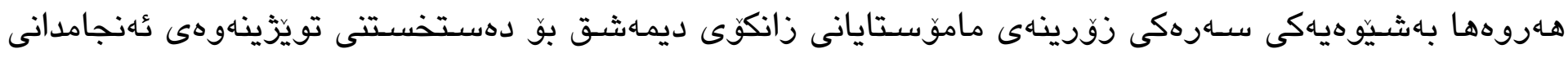

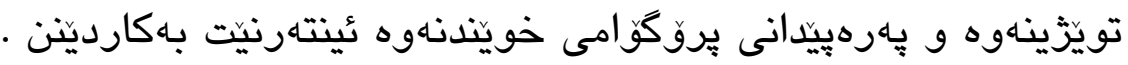


ناونيشـانى تويّزينهوهكه بريتى بوو له (اسـتخدام الإنترنت فى الأنشـطه الأكاديميه وغير الأكاديميه من وجهه نظر طلبه كليه الطب فى جامعه العلوم والتكنولوجيا الأردنيه والصـعوبات المتعلقه بهذا الاسـتخدام), ثامانجى تويّزينهوهكه بريتى

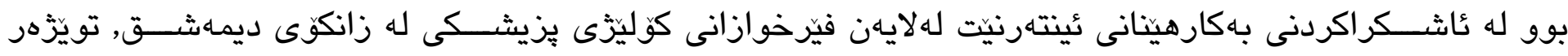

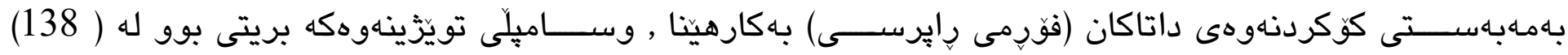
فيّرخواز.

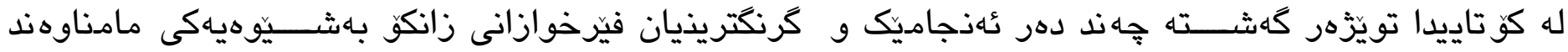

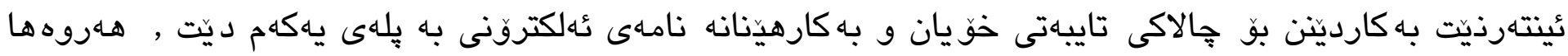

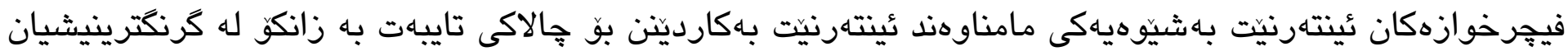
داتا و زانيارى تايبهت به وانهكانيان.

$$
\text { 3- تويّزينهوهى ( نـله , 2008-2009) }
$$

ناونيشـــانى تويّزينهوهكه بريتى بوو له (اثر اســتخدام الانترنات لدى الثـــاب الجامعى على وســـائل الإعلام التقليديه), ئامانجى تويّزينهوهكه بريتى بوو له عاثــــكراكردنى كاريكهرى بهكارهينانى ئينتهرنيت لهلايهن فيَرخوازانى

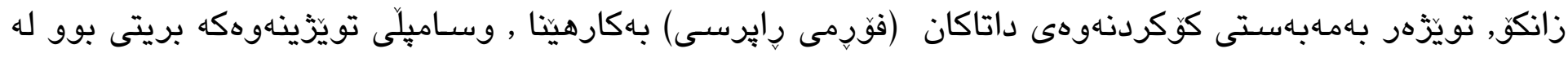

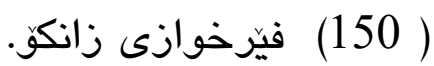

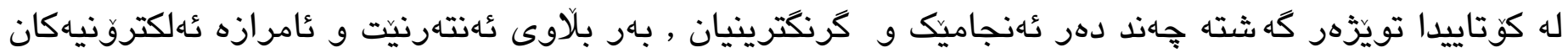

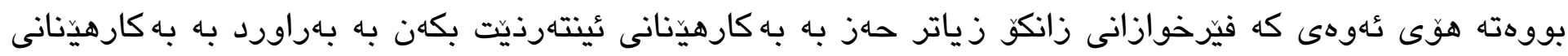
كُامرازه و ميديـاى كلاســيكى, هـروههـا زقورينهى فيرخوازان بهلايهنى كهمهوه له يهكيك له خزمـهتكوزاريهكانى ئيتهارنيت بـشدارى كردووه.

Pding

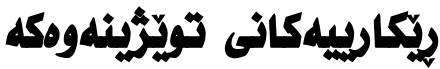

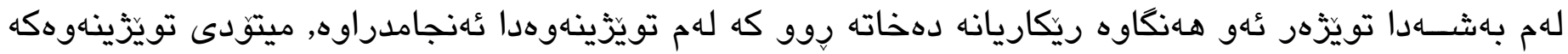

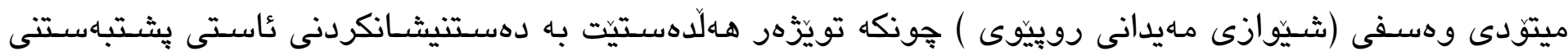

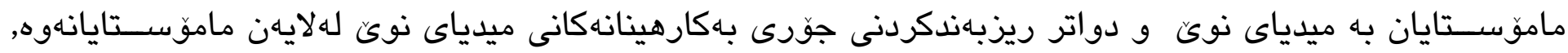

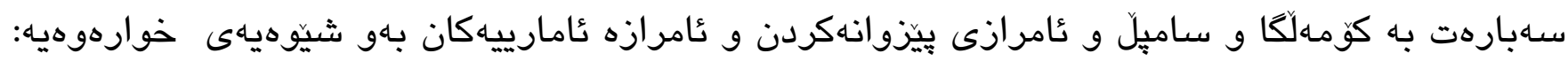




\section{يلمكهم : كوّمه لكاى تويَّرينهومكه:}

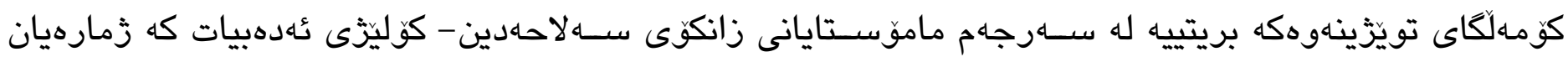
(245) مامؤستايه و (62) له رهكهزى مينّ و (173) له رهكهزى نيّزن, وهك له خشتهى ( 1 ) ) روونكراوهتهوه.

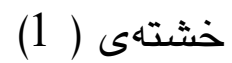

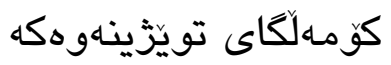

\begin{tabular}{|c|c|c|c|c|c|c|c|c|}
\hline \multirow[t]{2}{*}{ كو } & \multicolumn{4}{|c|}{ يله زى زانستى } & & & \multirow[t]{2}{*}{ بهش } & \multirow[t]{2}{*}{$\dot{j}$} \\
\hline & $\dot{ث}$ & ث.ي & $\hat{r}$ & م· ي & مي & نير & & \\
\hline 13 & 3 & 6 & 2 & 4 & 6 & 7 & دهروونزانى & 1 \\
\hline 37 & 5 & 8 & 14 & 10 & 12 & 25 & كوّمـلَّاسى & 2 \\
\hline 19 & - & 6 & 7 & 6 & 5 & 14 & راكهياندن & 3 \\
\hline 33 & 2 & 7 & 10 & 14 & 8 & 25 & جوكرافيا & 4 \\
\hline 28 & - & 7 & 11 & 10 & 8 & 20 & شويناهوار & 5 \\
\hline 62 & 14 & 5 & 25 & 18 & 18 & 44 & ميّزوو & 6 \\
\hline 28 & 1 & 5 & 3 & 20 & 7 & 21 & فهلسهافه & 7 \\
\hline 25 & - & 3 & 5 & 17 & 8 & 17 & كومـهالايهتى & 8 \\
\hline 245 & & & & & & & كوى كَثتى & \\
\hline
\end{tabular}

دووهم : ساميلّى تويّرَينهوهكه

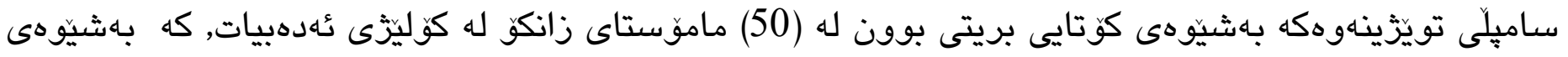
هـرهمهكى هـلَّزَيْردران , وهك له خشتهى ( 2) روونكراوهتهوه.

خشتهى (2) )

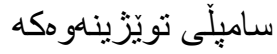

\begin{tabular}{|c|c|c|c|c|c|c|c|c|}
\hline \multirow[t]{2}{*}{ كو } & \multicolumn{4}{|c|}{ بلهى زانستى } & & & \multirow[t]{2}{*}{ بهش } & \multirow[t]{2}{*}{$j$} \\
\hline & 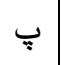 & ب״ى & $\hat{\imath}$ & v & مئ & نيّز & & \\
\hline 6 & 2 & - & 1 & 3 & 3 & 3 & دهرونزانى & 1 \\
\hline 9 & 1 & 2 & 3 & 4 & - & 9 & كؤمهلَّاسى & 2 \\
\hline 10 & - & 3 & 2 & 5 & 4 & 6 & راكَهياندن & 3 \\
\hline 7 & - & 2 & 2 & 3 & 3 & 4 & جوكرافيا & 4 \\
\hline 8 & - & 1 & 5 & 2 & 3 & 5 & شويتّنهوار & 5 \\
\hline 10 & 2 & 3 & 3 & 2 & 3 & 7 & ميّزُوو & 6 \\
\hline 50 & & & & & & & & \\
\hline
\end{tabular}




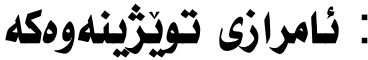

لهبهر نهبوونى ئامرازيكى بيّوانهكردنى ئاماده و كَنجاو تاييهت به (ئاستى بشتبهاهتنى ماموّستايان به ميدياى

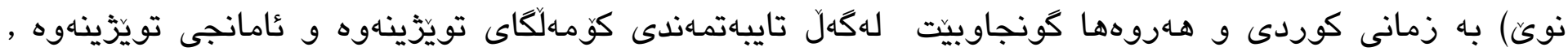

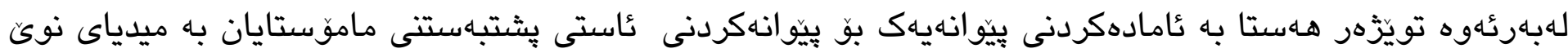

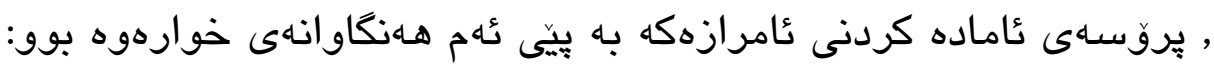

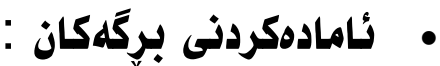

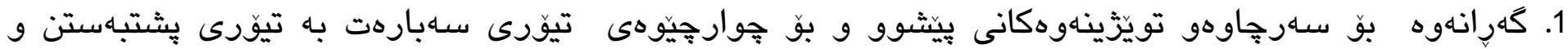

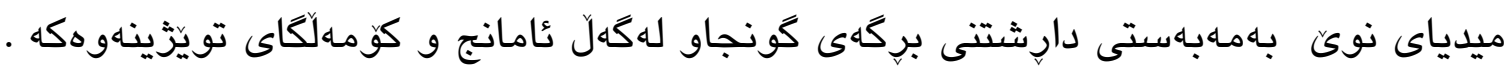

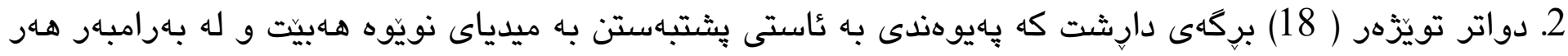

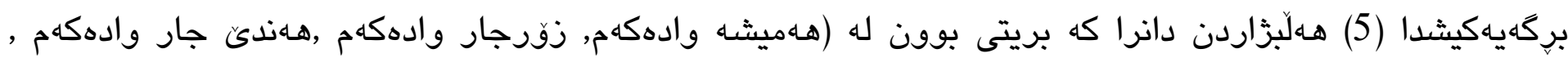

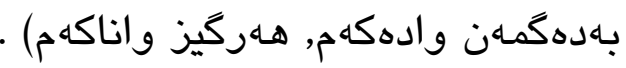

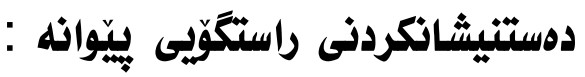

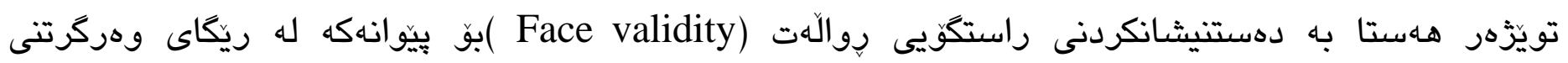

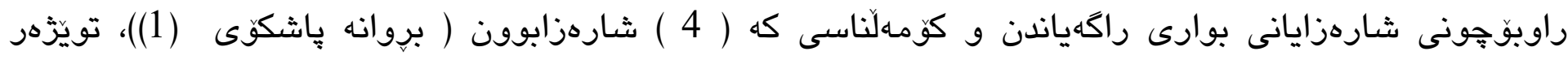

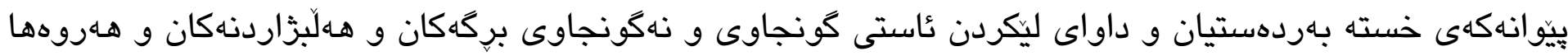

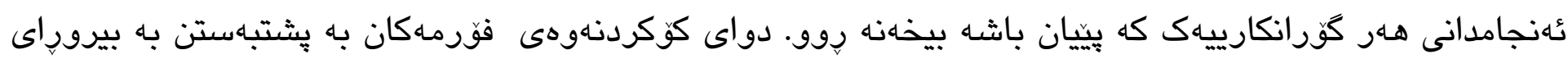
شارهزايان ئهم كَّرانكاريانه عُهنجامدرا:-

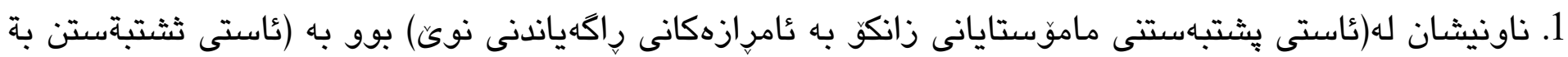
ئامرازةكانى ميدياى نوى لة للاى مامؤستايانى زانكؤى سـانلاحةدين).

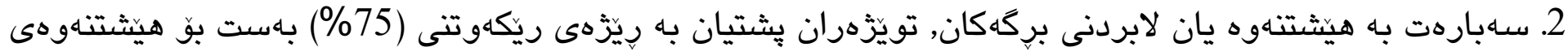

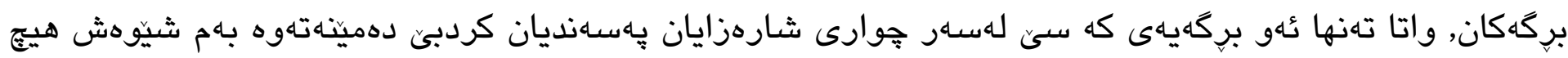
بركَهيه لانهانبرا.

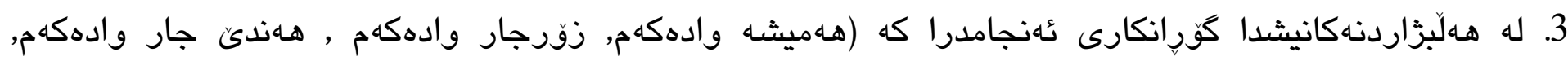

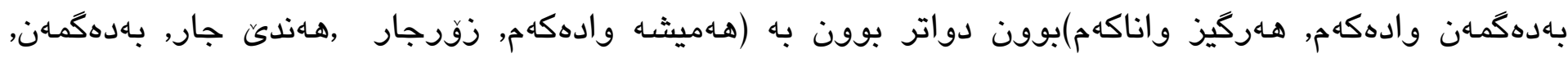

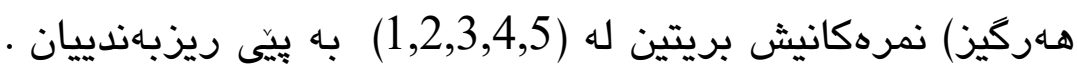

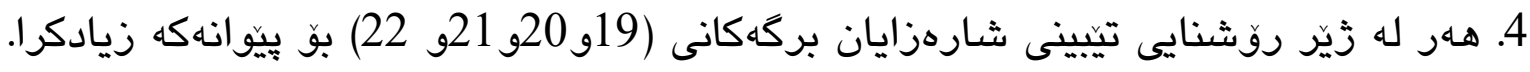

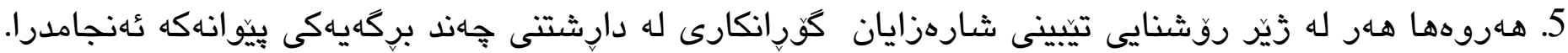




\section{دهستنيشانكردنى جيِّيَيرى بيِّوانه :}

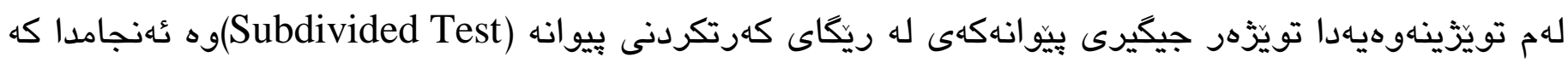

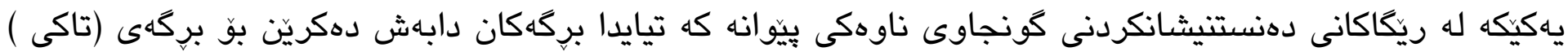

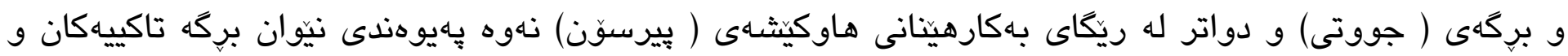

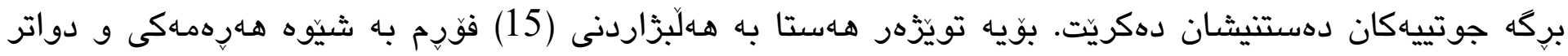

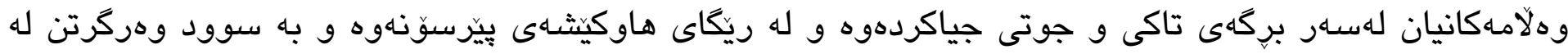

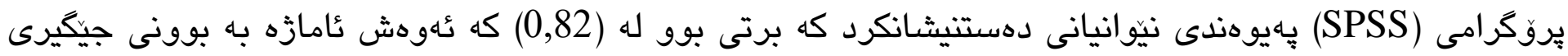

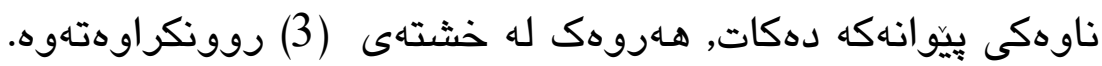

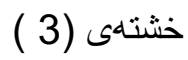

\begin{tabular}{|c|c|c|c|c|}
\hline \multicolumn{5}{|c|}{ يَحاى كهرتكردنى يِيّو ا: } \\
\hline 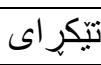 & زَمارهى بر گَكان & & 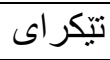 & زُمارهى بر گَهكان \\
\hline \multirow[t]{2}{*}{0,05} & \multirow[b]{2}{*}{82} & 6 & 15 & بركاى تاكى \\
\hline & & 5 & 15 & برگكلى جوت \\
\hline
\end{tabular}

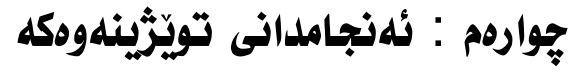

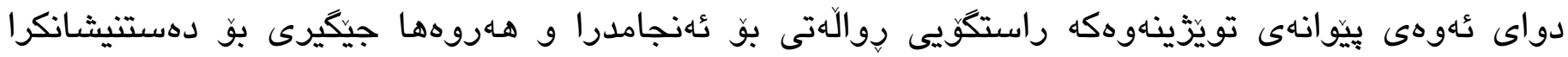

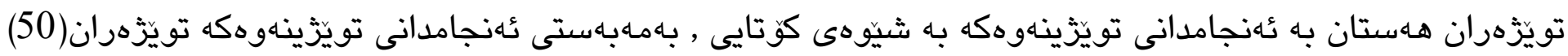

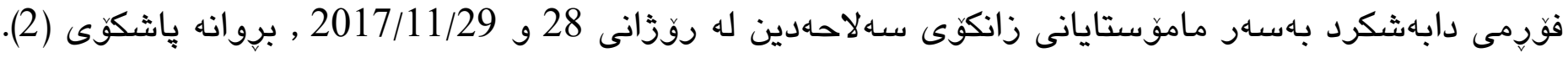

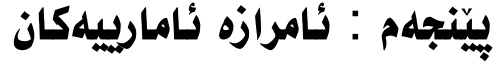

به مهابستى شيكردنهوهى ( داتاكان ) تويّزّهران سووديان له يروكرامى هـكَهى ئامارى بو زانسته

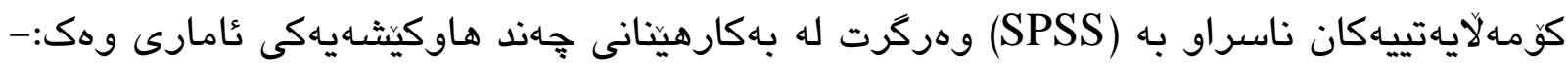

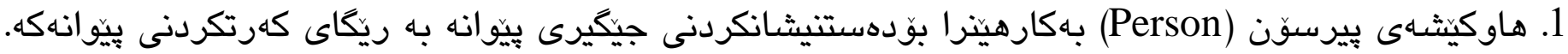

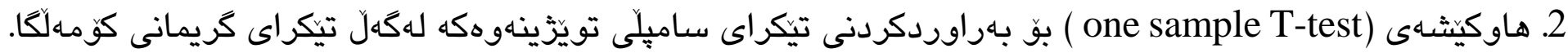

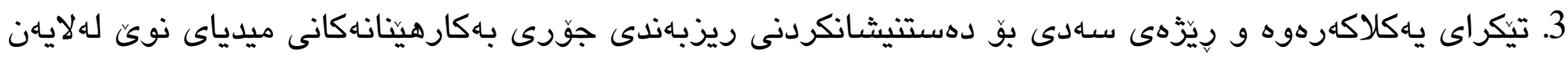
ماموستاكانهوه. 


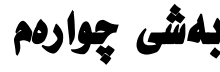

\section{تلهنجامكانى تويَّينهوومكه و شيكردثلهوميان}

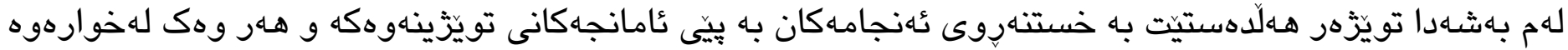

هاتووه :- (1)

يهكهم: سابارهت به ئامانجى يهكهم كه بريتى بوو له ئاشكراكردنى ئاستى يشتبهستى ماموستايانى زانكوىى

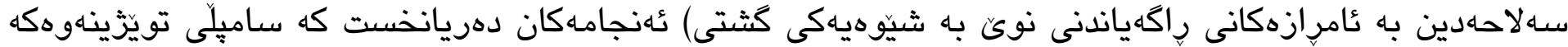

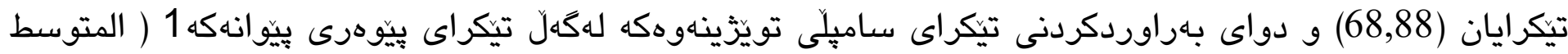

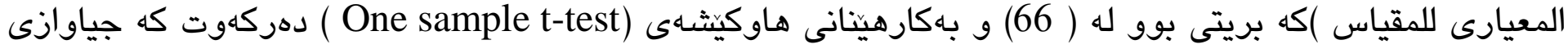

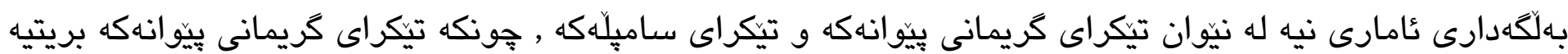

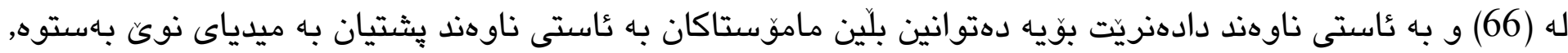
هـار وهك له خشته (4) رِونكراوهتهوه.

خشتهى (4) (1) )

ئاستى بشتبهستى ماموستايانى زانكوى سهلاحهدين به ميدياى نوىن

\begin{tabular}{|c|c|c|c|c|c|c|c|}
\hline بهألكادهارى & نُازادى & Sig & به هاى تائى & 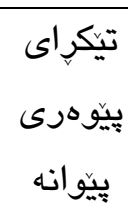 & بيَّهرى لادانى & تسكامِّلِ & سماميلّ \\
\hline 0.05 & 49 & 0,52 & 0,68 & 66 & 12,3 & 64,88 & 50 \\
\hline
\end{tabular}

دووهم : سهابارهت به ئامانجى دووهم كه بريتى بوو ئاشكراكردنى ريزبهندكرنى جوّى بهكارهينانهكانى ميدياى نوكن له لايهن مامؤستايانهوه و دياريكردنى ناوهندى زميرهيى(الوسط الحسابى), دواى دهستتيشانكردنى تيكراى

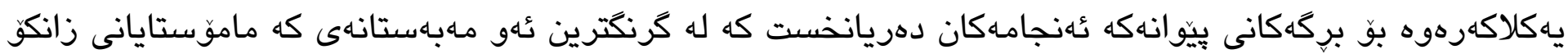

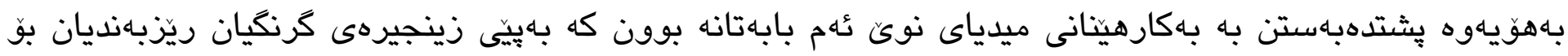

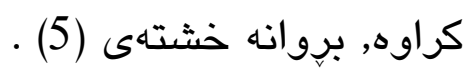

خشتهى (5)

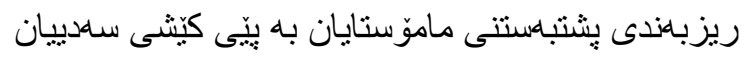

\begin{tabular}{|c|c|c|c|}
\hline سليشى & ياكلاك كنر هوه & برگذكان به يِيْى كيّشى سهدييان & زبركة \\
\hline$\% 64.3$ & 3,21 & 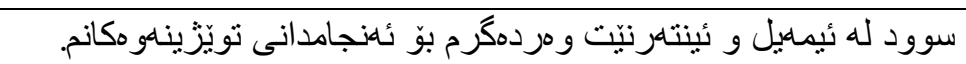 & 4 \\
\hline
\end{tabular}

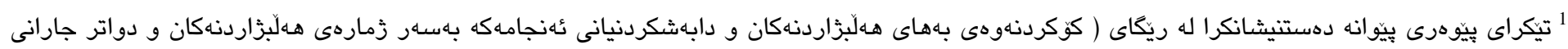

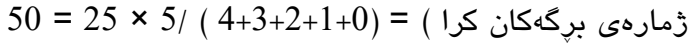




\begin{tabular}{|c|c|c|c|c|}
\hline$\% 63$ & 3,15 & بوّ زانينى دوا رووداو و هلو اللّكان سود لله ئينتكرنيّت وهردهُرم. & 21 & 2 \\
\hline$\% 60,65$ & 2,86 & بو زانينى بابهته سياسيهكان ئينتارنيّت بهكاردهدينّن. & 22 & 3 \\
\hline$\% 57,3$ & 2,86 & 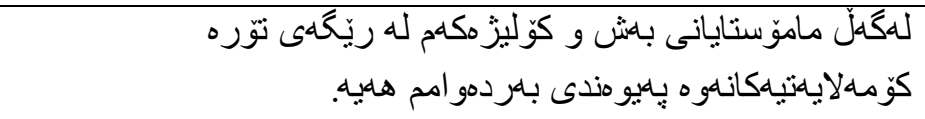 & 20 & 4 \\
\hline$\% 55,65$ & 2,78 & 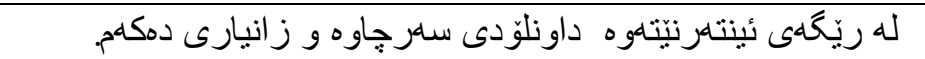 & 11 & 5 \\
\hline$\% 54$ & 2,7 & 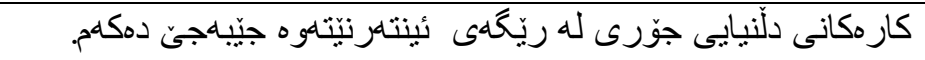 & 9 & 6 \\
\hline$\% 52,3$ & 2,61 & 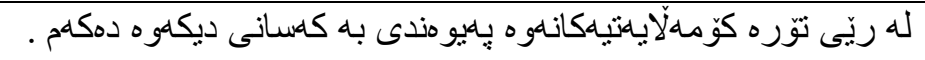 & 3 & 7 \\
\hline$\% 50,3$ & 2,515 & 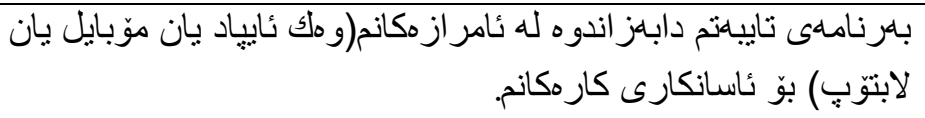 & 13 & 8 \\
\hline$\% 50$ & 2,50 & 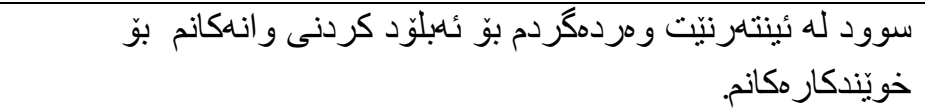 & 5 & 9 \\
\hline$\% 47,65$ & 2,38 & بوّ بهسامربردنى كاتيّكى خوّش يُينتهرنيت بهكاردههيّنم. & 1 & 10 \\
\hline$\% 46$ & 2,3 & 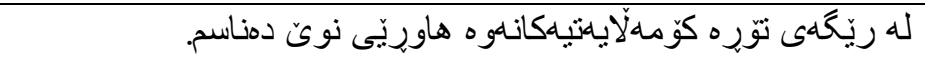 & 7 & 11 \\
\hline$\% 46$ & 2,3 & 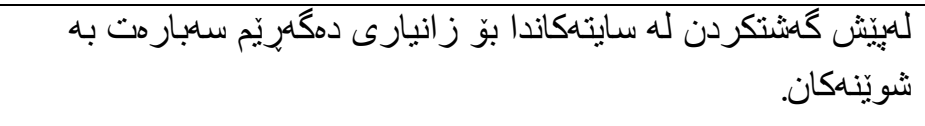 & 6 & 12 \\
\hline$\% 38$ & 1,9 & قيديوّكانى ئينتهرنيّت للهو انهكاندا بهكارده هيّنم. & 14 & 13 \\
\hline$\% 36,4$ & 1,82 & 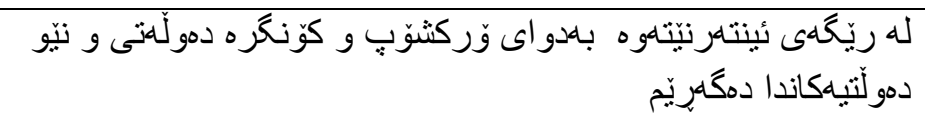 & 10 & 14 \\
\hline$\% 26,2$ & 1,32 & بوّ وهركرتنى زانيارى ئايينى سايتهجياجياكان بهكاردههينان. & 15 & 15 \\
\hline$\% 24,4$ & 1,22 & 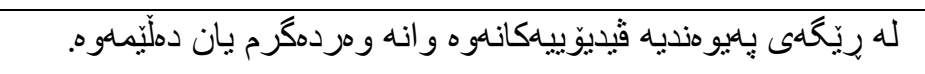 & 12 & 16 \\
\hline$\% 24,4$ & 1,22 & 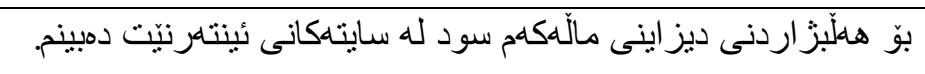 & 18 & 17 \\
\hline$\% 30$ & 1,5 & بهاهوَى سايتى تاييهتاهوه خوّم فِّرى زمانى ديكه دهبم. & 8 & 18 \\
\hline$\% 24$ & 1,2 & 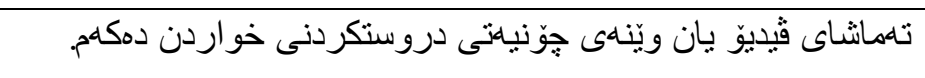 & 16 & 19 \\
\hline$\% 20$ & 1 & 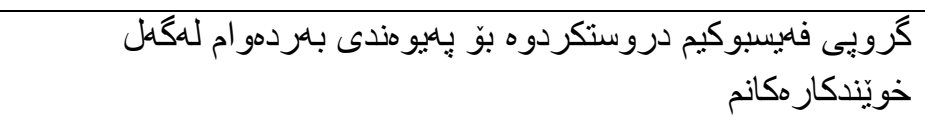 & 19 & 20 \\
\hline$\% 16$ & 0,8 & بينينتهرنيت بهكاردينم بوّ زانيارى للهسار ئهو كالايانهى كه دهماويّت & 2 & 21 \\
\hline$\% 16$ & 0,8 & 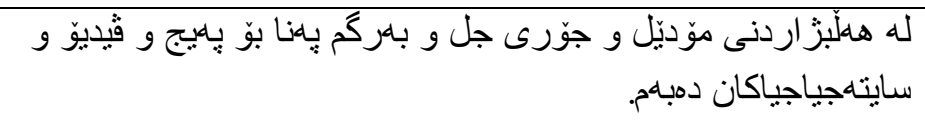 & 17 & 22 \\
\hline
\end{tabular}

1.بركَهى (سوود له ئيمـيل و ئينتهرنيت وهردهُرم بو ئهنجامدانى تويّزينهوهانم ) بهرزترين پِلهى وهركرتوه كه

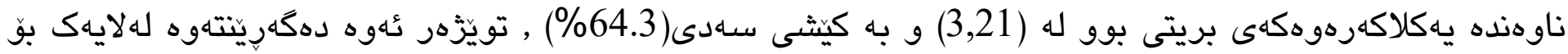

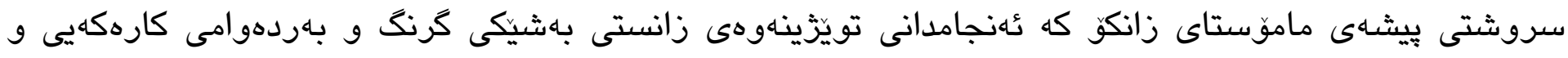

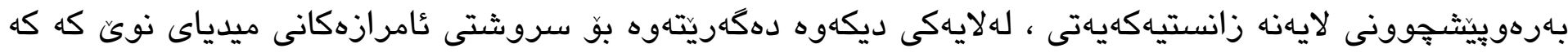
كتيب و زانيارى و سـرجهاوهى زانستى بحَّ شوماريان خستوته بهردهست به خيّراييهكى زوّر و تيجّوويهكى كهم. 


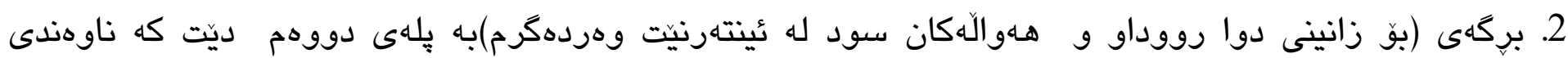

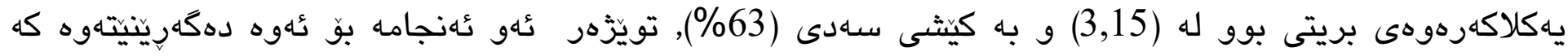
زانينى هـاوال و زانيارى جيّى بايهخى ماموّستايانى زانكويه, بوّيه بو بهدهستهينانيان يشت دهبهستن به ميدياى نوىّ بوّ بـداهستهينيانيان.

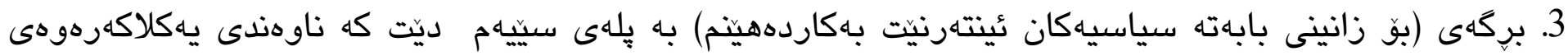

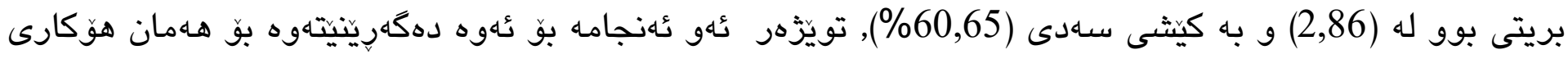
بركَّى يِينشوو.

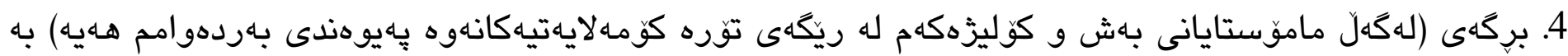

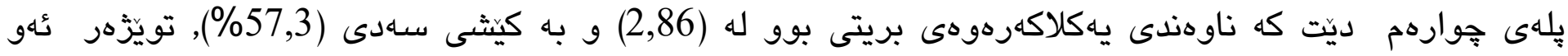

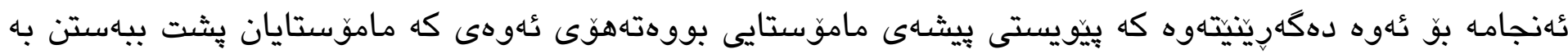

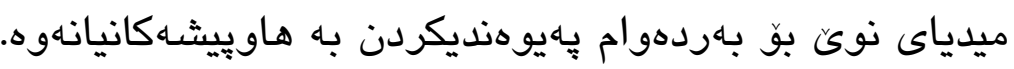

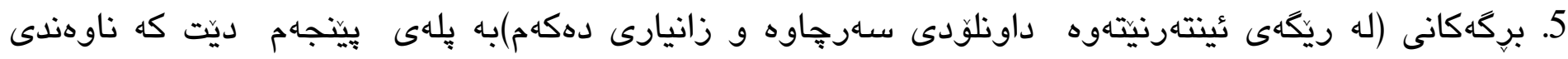

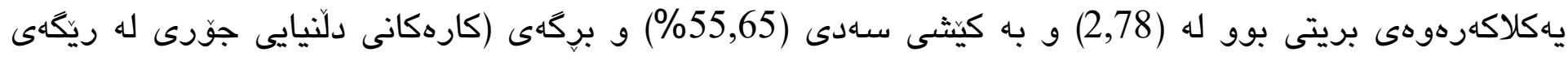

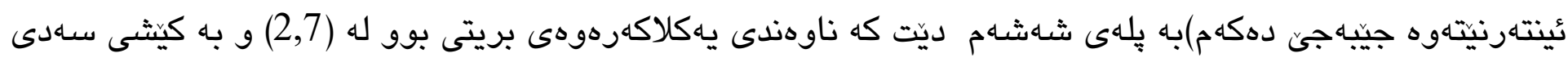

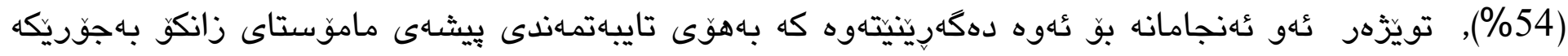
يِيّويسته بو كاره هـنوكهييهكامى يشت بيهستن به ميدياى نوكّ.

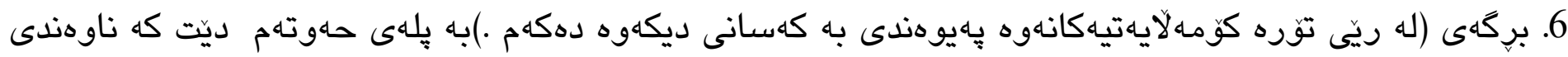

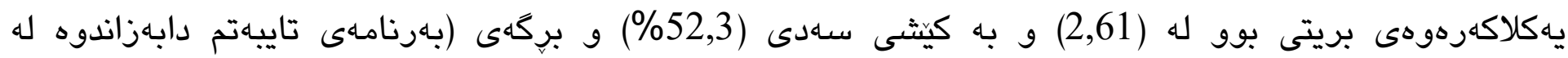

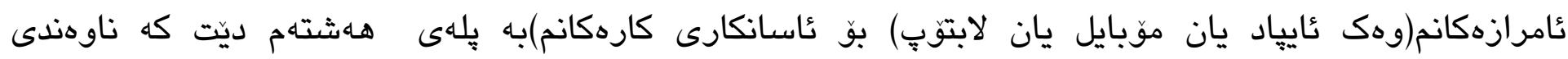
يه كلاكهرهوهى بريتى بوو له (2,515) و به كيشى سهدى (50,3\%) و بركَى (سوود له ئيتهرنيت وهردهكردم بو

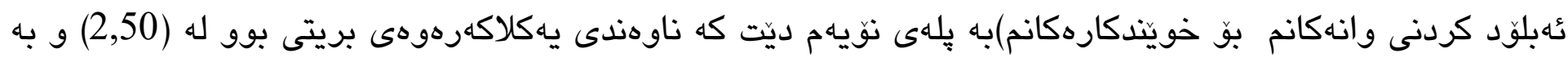

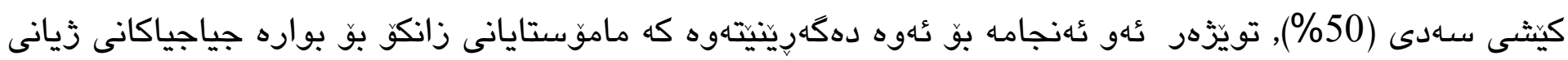

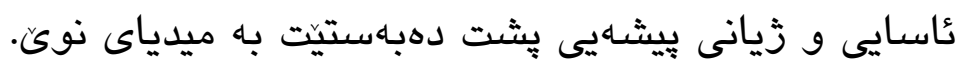

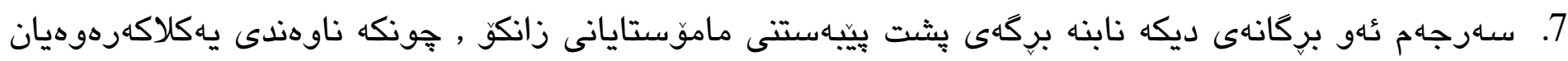
له (2,5) و كيشى سـهديان له (50\%) كهمتره, به وردبونهوه له بركگكان دهبينين كه زياتر تُهو لايهنانه لهخو دهكرن

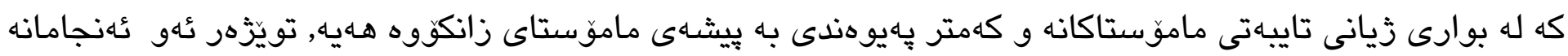

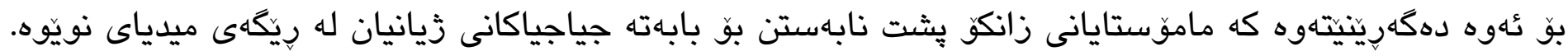




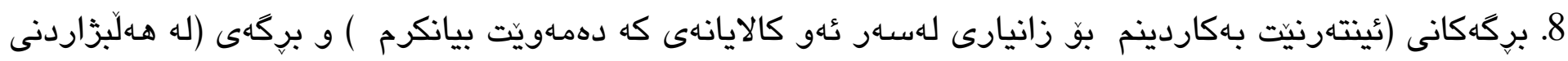

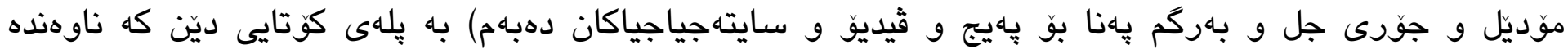

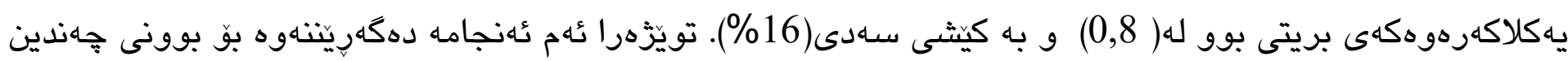

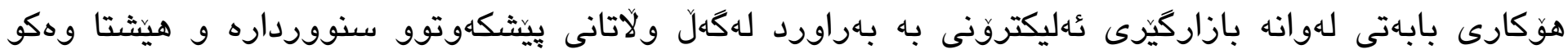

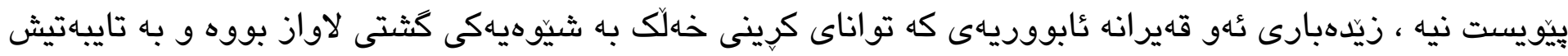

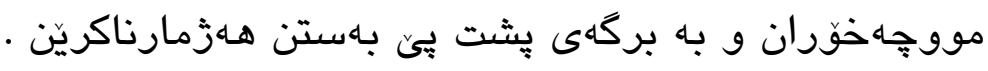

دروئلزذجامهكاز:

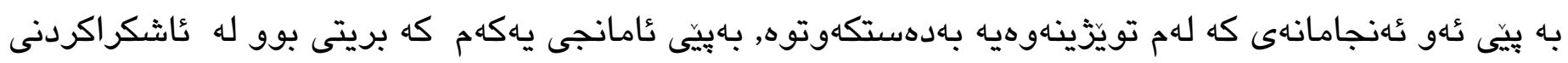

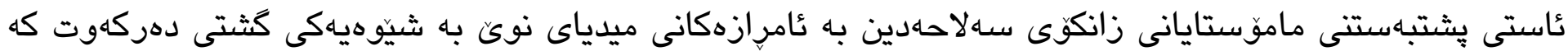

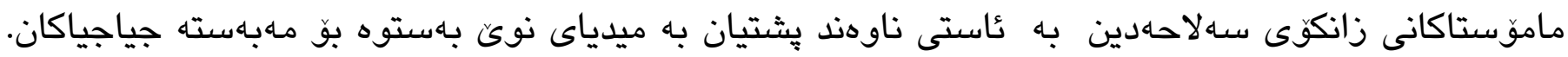
سـابارهت به ئامانجى دووهم كه بريتى بوو عاشكراكردنى ريزبهندكرنى جوّرى بهكارهينانهانى ميدياى نوىّ له

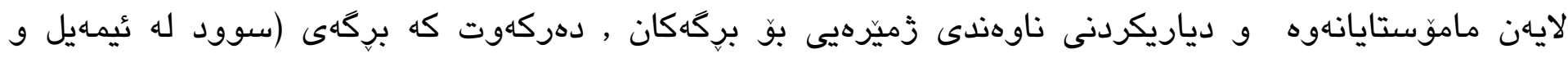

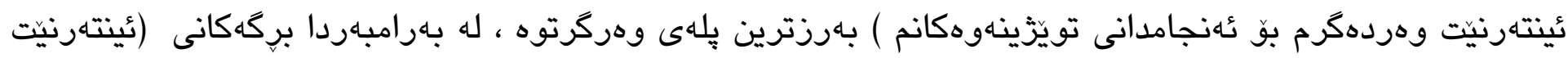

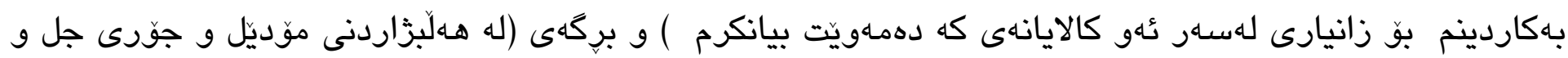

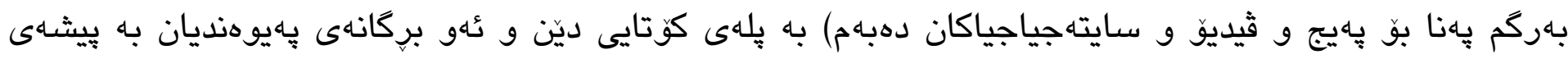

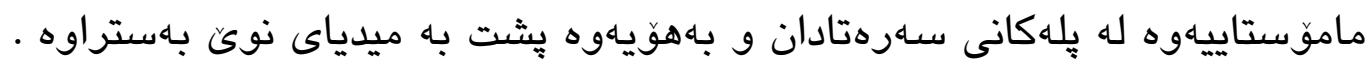

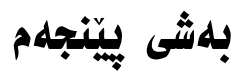

راسيارده و يِيشنياروكان

يلهكdم : راسبياردوكاز

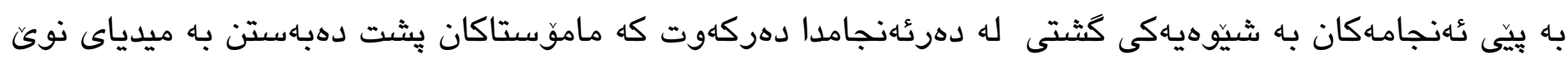
بوّ مـهبهسته جياجياكان , بوّيه يِيّويسته زانكوَى سـلاحهـدين كارئاسـانى بو ماموّستاكان بكات بوّ فهراهـمكردنى ميدياى

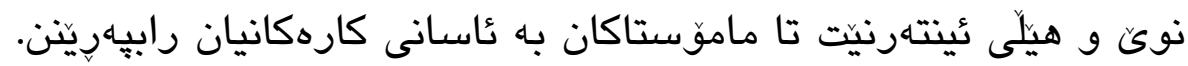

دووهم : بيِشنيارهكان

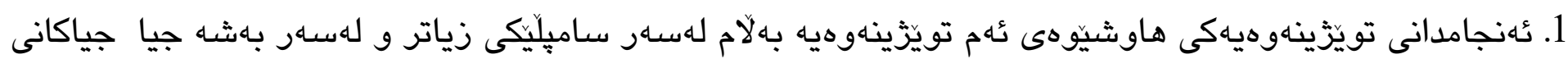
ديكهاش.

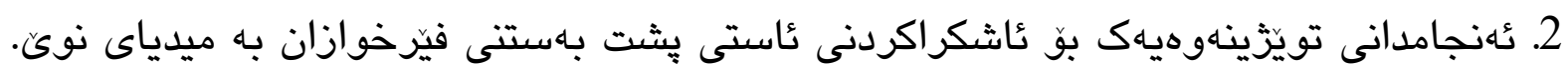




\title{
The Level of Dependency of The Lecturers of Salahaddin University On The New Media
}

\author{
Jwan Bahaden Ali \\ Education and Psychology Department, Education Faculty, Koya University, Koya, Kurdistan \\ Region, Iraq. \\ E-mail: jwan.bahaden@koyauniversity.org
}

\begin{abstract}
Abdulkhalq Ibrahim Mustaffa
Media Department, Erbil Technical Admnistrative Institute, Erbil Polytechnic University, Erbil, Kurdistan Region, Iraq.

E-mail: abdulkhaliq.mstaffa@epu.edu.iq
\end{abstract}

\begin{abstract}
:
The aim of this study that to expose the level of dependency of the lecturers of Salahuddin University on the new media, generally, in education process and determine their use of these tools and determinie the arithmetical average of these uses. For this purpose, specific criteria have been set for measuring the level of dependency, after identifying the Face validity and consistency of the measurement content, the researchers distributed randomly (50) questionnaires to the lectures who were (33) males and 17 females.

the results showed that the lectures depend on new media on medium, that lectures depend on new media for e-mail and the Internet to conduct their research as the ferst recuer, in contrast lectures less depend on new media for getting information about the goods they want to buy or to choose the fashion and type of clothing.
\end{abstract}

Keywords: Level, Dependency, New Media. 
حجاب، محمد منير (2010) نظريات الأتصال ،ط 1، دار الفجر للنشرو التوزيع ،القاهرة. حسونة، نسرين (2014) الاعلام الجديد المفهوم و الوسائل و الخصائص و الوظائف ، النسخة الألكترونية ، شبكة الألوكة.

الخطيب, لطفي(2011) استخدام الإتترنت في الأنشطة الأكاديمية وغير الأكاديمية من وجهة نظر طلبة كلية الطب في جامعة العلوم والتكنولوجيا الأردنية والصعويات المتعلة بهذا الاستخدام, مجلة جامعة دمشق - المجلد 27 -العدد الثالث + الرابع. الزرن، جمال (2007) دراسة بعنوان سلطة التدوين، مجلة الشؤون العربية على النت، 31 يوليو، العد130. سليم، حنان احمد (2016) الحملات الأعلامية عبر الأعلام الجديد ، الطبعة الثانية ، جامعة ملك سعود. شقرة، علي خليل (2010) الأعلام الجديد (شبكات التواصل الأجتماعي) ، ط1، دار اسامة و دار نبلاء ، عمان. شقير، بارعة حمزة (2009) استخدام اساتذة الجامعة دمثق للانترنت و الاشباعات الحققة منها، مجلة جامعة دمثق,العدد الاول الثاني.

صادق، عباس مصطفى (2006) الإعـلام الجديد دراسة في تحولاته التكنولوجية وخصـائصه العـامة ،الأمارات العربية المتحدة. عبدالحميد،.محمد (2006) ،نظريات الأعلام و اتجاهات التأثير،ط3،عالم الكتب للنشر والتوزيع و الطباعة،القاهرة. 
فــلة ,قيدوم(2008-2009) اثر استخدام الانترنات لدى الثباب الجامعي على وسائل الإعلام التقليدية,رسالة ماجستير غير منشورة, جامعة الجزائر بن يوسف بن خده-كلية العلوم السياسية والإعلام-قسم علوم الإعلام والاتصال.

الفيصل، عبدالأمير (2014) دراسات في الأعلام الألكتروني ، ط1 ، دار الكتاب الجامعي ، الأمارات العربية المتحدة.

مكاوي، حسن عماد. السيد، و ليلى خسين (2006) الأتصال و نظرياته المعاصرة ،ط6،الدار المصرية اللبنانية،القاهرة.

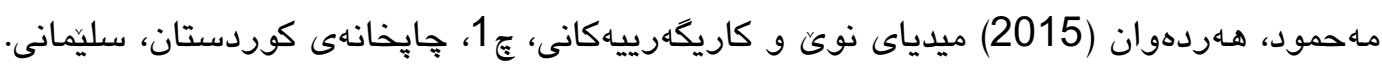

ئيبراهيم، عهبدولخالق (2014) ميدياى كوردى لهسهردهمى ثاسمانه كراوهكاندا، ج1، خانهى موكريانى بوّ جاب و بلّاوكردنهوه، هـاوليَر.

Manovich, L. (2001) The Language of New Media, New York University, New York.

Pasadeos, Y. (2010) Advances in Communication and Mass Media Research, Athens Institute for Education and Research.

Shilpa, J. (2014) New Media Technology In Education - A Genre Of Outreach Learning, Global Media JournalIndian Edition, Summer Issue, Vol. 5/No. 1

Watt, K. F. Allan, S. (2013) Journalism: New Challenges, Published by: Centre for Journalism \& Communication Research Bournemouth University. 
ياشكوَكان

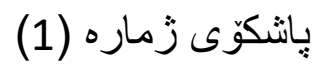

ناو و ناونيشانى شار هز ايان

\begin{tabular}{|c|c|c|c|}
\hline شوينى كار & ي بِيْوِرى & ناوى سيانى يِسيٌّوران & j \\
\hline 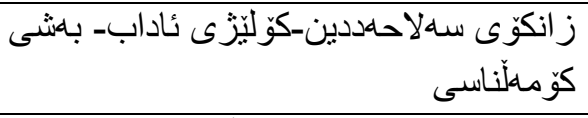 & كوّ مهالْناسى & ״ .د.طاهر حويز زيبارى & 1 \\
\hline يوّ ليتهكنيكى سليّمانى - ر راكهياندن & ر اكمياندن & ب.ى.د. يهحيا عومهر ريّثاوى & 2 \\
\hline زانكوّى رايهرين & ر راكمياندن & بِ.ى.د. هيَرش رسول موراد & 3 \\
\hline 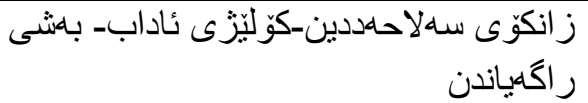 & ر اكمياندن & ب.ى.د. عَاريانه ابراهيم & 4 \\
\hline
\end{tabular}

باشكوَى (2)

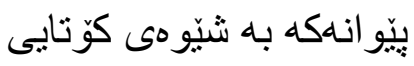

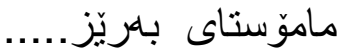

پֶاش سلّاو

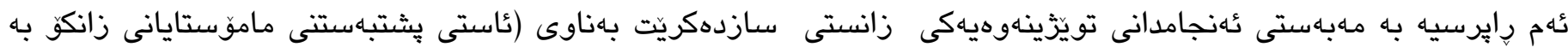

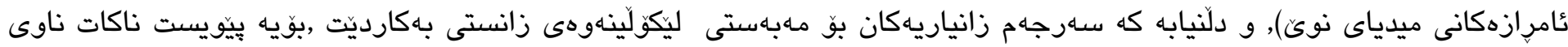

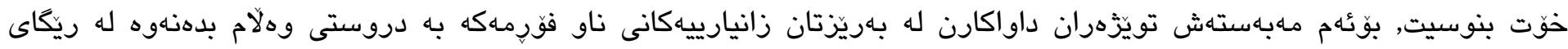

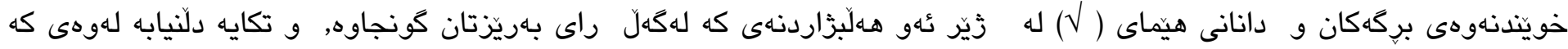

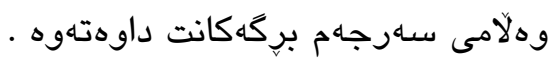

هاوكاريتان جينَاى رِيَزه.

يرسياره كثتيه كان: 1 : 2

3. يُلهى زانستى:ماموّستاى ياريدهدهر ( ) ماموّستا( ) بِروَفيسوّرى ياريدهدهر( ) بِروَفيسوّر( )

\begin{tabular}{|r|r|r|r|r|r|c|}
\hline & & & \\
\hline \\
\hline
\end{tabular}




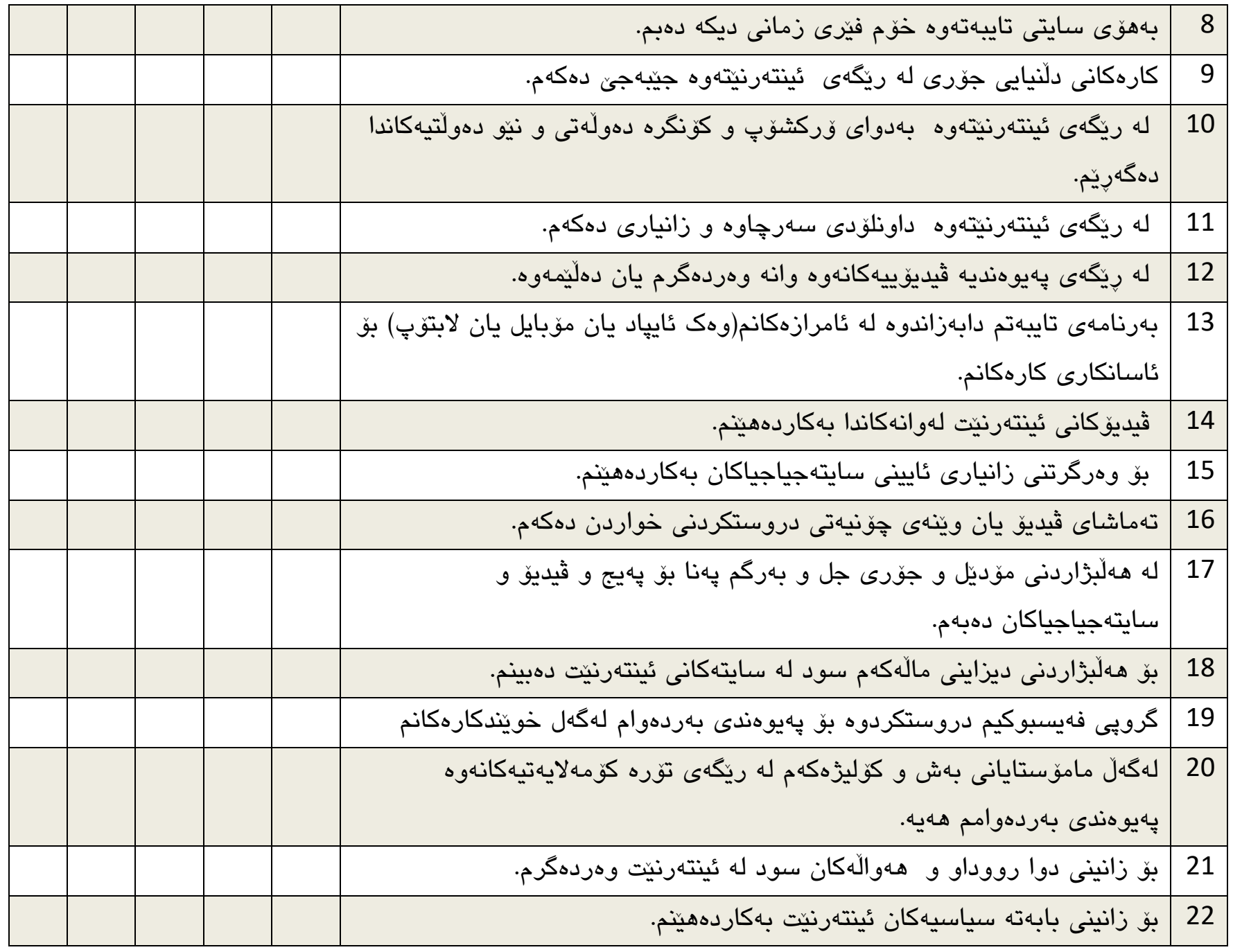

